\title{
ANALIZA TRŽIŠTA OSIGURANJA NA TERITORIJI SRBIJE ZA PERIOD OD 2014. DO 2018. GODINE
}

\section{ANALYSIS OF THE INSURANCE MARKET IN THE TERRITORY OF SERBIA FOR THE PERIOD FROM 2014 TO 2018}

\author{
Milan Bradić, Fakultet tehničkih nauka, Novi Sad
}

\begin{abstract}
Oblast - INŽENJERSKI MENADŽMENT
Kratak sadržaj - U ovom radu prikazane su teorijsko metodološke osnove osiguranja sa posebnim osvrtom na životno $i$ neživotno osiguranje, kao i osnovne podele osiguranja i osnovni pojmovi u osiguranju. Predstavljena je analiza tržišta životnog $i$ neživotnog osiguranja $u$ Republici Srbiji u periodu od 2014. do 2018. godine $i$ data je komparativna analiza u posmatranom periodu.
\end{abstract}

Ključne reči: Osiguranje, premija osiguranja, životno osiguranje, neživotno osiguranje, tržište osiguranja

Abstract - In this work theoretical-methodological fundamentals of insurance with a special emphasis on life and non - life insurance are presented, as well as basic insurance segments and basic insurance concepts. An analysis of the life and non-life insurance market in the Republic of Serbia in the period 2014 - 2018 is presented and a comparative analysis is provided for the observed period.

Keywords: Insurance, insurance premium, life insurance, non-life insurance, insurance market

\section{UVOD}

Tržište osiguranja u Srbiji i pored negativnog uticaja svetske ekonomske krize beleži usporeniji rast i blago poboljšanje strukture premije osiguranja u korist životnih osiguranja. Postoji puno prostora za rast tržišta osiguranja u Srbiji, kroz agresivniji pristup osiguravajućih kompanija u promovisanju aktivnosti, pri čemu bi se pojačala konkurencija između njih, što bi značajno uticalo na širenje tržišta.

Međutim svakako je neophodna podrška države u smislu izmene i dopune Zakona o osiguranju, kao i uvođenje poreskih olakšica za sve osiguravajuće kompanije koje žele da investiraju u privredu. Sa druge strane osiguravajuće kompanije treba da rade na edukaciji i podizanju svesti stanovništva o osiguranju, ali i stvaranjem proizvoda koji su prihvatljivi za postojeći životni standard u Srbiji.

\section{POJAM I ZNAČAJ OSIGURANJA}

Osiguranje predstavlja zaštitu imovinsih interesa fizičkih i pravnih lica prilikom realizacije rizika, odnosno natupanja osiguravajućih slučajeva, na račun fondova osiguranja formiranih naplatom premija od tih lica [1].

\section{NAPOMENA:}

Ovaj rad proistekao je iz master rada čiji mentor je bio dr Đorđe Ćosić, vanr. prof.
Osiguranje ima veliku ulogu kako unutar jedne zemlje tako i na međunarodnom nivou. Takođe, ima dvojaku ulogu, a to je da zaštiti osiguranu imovinu i lica kao i da ostvari profit.

Danas je osiguranje visoko razvijena društvena delatnost koja obezbeđuje ekonomsku zaštitu osiguranicima, pravnim i fizičkim licima od štetnih dejstava i poremećaja do kojih dolazi nastankom osiguranog slučaja ili ostvarenjem osiguranog rizika [1].

\section{PODELA OSIGURANJA}

Osnovna podela osiguranja je na životno i neživotno osiguranje.

Životno osiguranje je specifična vrsta osiguranja koja uključuje i štednju. Životno osiguranje omogućuje finasijsku sigurnost koja se obezbeđuje posedovanjem polise, gde u slučaju smrti osiguranika korisniku se isplaćuje osigurana suma i na taj način mu se pruža finasijska pomoć. Osnovna svrha životnog osiguranja je briga o budućnosti. Ovaj vid osiguranje je veoma rasprostanjen po svetu posebno u ekonomski razvijenim zemljama. Kod životnog osiguranja se ne može primeniti pravilo o nad ili podosiguranju, ono što je veoma karakteristično za životno osiguranje naspram ostalih, jeste kumuliranje osiguranih suma po više ugovora osiguranja. Vrste životnog osiguranja: [3]

- osiguranje života

- rentno osiguranje

- dobrovoljno penzijsko osiguranje

- dopunsko osiguranje uz osiguranje života

- druge vrste životnih osiguranja.

Neživotno osiguranje je vrsta osiguranja gde ugovor najčešće traje do godinu dana (kratkoročno osiguranje). Prilikom nastanka štete osiguravač tačno može da utvrdi visinu nastale štete koju treba da nadoknadi uz pomoć načela obeštećenja i načela materijalnog interesa, i za razliku od osiguranja života ovde se ne koriste tablice smrtnosti. Načelo obeštećenja je načelo koje podrazumeva da osiguravač treba da izvrši nadoknadu štete maksimalno do visine štete, a načelo materijalnog interesa daje obavezu osiguraniku da čini sve da do štete ne dođe, a ukoliko se ipak dogodi šteta biće mu nadoknađena. Vrste neživotnih osiguranja:

- osiguranja autoodgovornosti

- osiguranje nezgode

- dobrovoljno zdravstveno osiguranje

- osiguranje motornih vozila 
- osiguranje šinskih vozila

- osiguranje vazduhoplova

- osiguranje plovnih objekata

- osiguranje robe u prevozu

- ostala osiguranja imovine

- osiguranje imovine od požara

- osiguranje opštih odgovornosti

- osiguranje kredita

- osiguranje jemstva

- osiguranje finansijskih gubitaka

- osiguranje troškova pravne zaštite

- druge vrste neživotnih osiguranja. [3]

\section{TRŽIŠTE OSIGURANJA U REPUBLICI SRBIJI ZA PERIOD OD 2014. DO 2018. GODINE}

U periodu od 2014.godine do 2016.godine bitno je istaći da je globalni rast ekonomske aktivnosti bio pozitivan ali umeren. Tendencija rasta bruto domaćeg proizvoda izražena u procentima kretala se od 2,3\% u 2016 do 2,5\% u dve godine koje su joj predhodile. Niske cene dobara i usluga, niske kamatne stope, i inflacija koja je bila na niskom nivou su najznačajniji faktori koji su uticali na rast ekonomske aktivnosti.

Tabela 1. Učešće premija životnih i neživotnih osiguranja (na osnovu javno dostupnih podataka NBS)

\begin{tabular}{|c|c|c|}
\hline God. & $\begin{array}{c}\text { Premija životnih } \\
\text { osiguranja } \boldsymbol{u} \%\end{array}$ & $\begin{array}{c}\text { Premija neživotnih } \\
\text { osiguranja } \boldsymbol{u} \%\end{array}$ \\
\hline 2014 & $4,8 \%$ & $2,5 \%$ \\
\hline 2015 & $4 \%$ & $3,6 \%$ \\
\hline 2016 & $5,4 \%$ & $2,4 \%$ \\
\hline
\end{tabular}

Kao što vidimo $\mathrm{u}$ tabeli premija životnog osiguranja najveću tendenciju rasta beleži u periodu između 2015. i 2016. godine, gde je učinak rasta zemalja u razvoju imao čak 20,1\%. Premija životnih osiguranja se u ovom periodu povećala prosečno za 3,67\%, dok je kod premije neživotnih osiguranja taj prosek manji i iznosi 2,9\%. Prema podacima Narodne banke Srbije najveći učinak u povećanju ukupne premije osiguranja imaju zemlje u razvoju, a realan rast beleže i zemlje u razvoju. Region Centralne i Istočne Evrope je u ovom periodu varirao, pa je u 2014.i 2016. godini zabeležio relan rast, a u godini između relan pad od 4,5\%.

\subsection{Učesnici na tržištu osiguranja}

Sektorska analiza tržišta osiguranja u Republici Srbiji obuhvata četvorogodišnji period od 2014. - 2017. godine, a najčešće korišćeni parametri stepena razvijenosti tržišta osiguranja su: odnos ukupne premije i domaćeg bruto proizvoda i ukupna premija po stanovniku. Kako je Narodna banka Srbije ovlašćena da sprovodi nadzor nad obavljanjem delatnosti osiguranja uspostavljna je metodologije izveštavanja učesnika na tržištu, koje je zadržalo kontinuitet, pa su podaci uporedivi i moguće je uočavati i pratiti trendove.

Kao početna godina analize opštih parametara, uzeta je 2014. godina kada je u Srbiji poslovalo 25 društava za osiguranje, od čega su se poslovima reosiguranja bavila četiri društva a poslovima osiguranja 21 društvo. Taj broj se iz godine u godinu neznatno smanjivao.
Tabela 2. Broj osiguravajućih i reosiguravajučih društava po godinama (na osnovu javno dostupnih podataka NBS)

\begin{tabular}{|c|c|c|c|}
\hline రి & $\begin{array}{c}\text { Br. društava za } \\
\text { osiguranje }\end{array}$ & $\begin{array}{c}\text { Poslovi } \\
\text { reosiguranja }\end{array}$ & Poslovi osiguranja \\
\hline 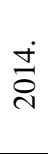 & 25 & 4 & $\begin{array}{c}21 \text { (6 isključivo } \\
\text { životno osiguranje, } 9 \\
\text { isključivo neživotno, } 6 \\
\text { meštovito) }\end{array}$ \\
\hline$\frac{\dot{n}}{\delta}$ & 24 & 4 & $\begin{array}{c}20 \text { (6 isključivo } \\
\text { životno osiguranje, } 9 \\
\text { isključivo neživotno, } 6 \\
\text { meštovito) }\end{array}$ \\
\hline$\stackrel{\dot{0}}{\stackrel{0}{\sigma}}$ & 23 & 4 & $\begin{array}{c}19 \text { (5 isključivo } \\
\text { životno osiguranje, } 8 \\
\text { isključivo neživotno, } 6 \\
\text { meštovito) }\end{array}$ \\
\hline
\end{tabular}

Ukoliko posmatramo broj ulazaka i izlazaka društava za osiguranje u periodu 2014.-2016. godine, uočavamo da je u 2014. godini poslovalo 21 društvo za osiguranje, dok je u 2015. godini broj društava bilo 20. U 2014. godini je društvo Uniqa životno osiguranje pripojilo Basler životno osiguranje, pa je usled statusne promene društvo Basler životno osiguranje obrisano iz registra dok je Uniqa neživotno osiguranje pripojilo Basler neživotno osiguranje, pa je usled statusne promene društvo Basler neživotno osiguranje obrisano iz registra. Pored navedenih društava, među učesnicima na tržištu osiguranja koji su prestali da obavljaju delatnost je i Takovo osiguranje, kome je 2014. godine NBS oduzela dozvolu za obavljanje poslova osiguranja i nad kojim je rešenjem Privrednog suda otvoren postupak likvidacije društva. Transfer portfelja neživotnog osiguranja društva Takovo osiguranje na društvo Dunav osiguranje ado Beograd, obuhvatio je samo neistekle polise u momentu transfera. U 2015. godini je tržište osiguranja napustilo i društvo Metlife, koje je prodajom poslednjeg dela svog portfelja životnog osiguranja društvu Generali osiguranje, napustilo tržište osiguranja Republike Srbije. Posmatrano prema vlasničkoj strukturi oko $75 \%$ kapitala je u stranom vlasništvu.

\subsection{Premija osiguranja}

Premija je suma novca koju osiguranik plaća kao cenu osiguranja. Sa stanovišta društava za osiguranje, ukupna (bruto) premija je iznos koji treba da pokrije iznos neto ili funkcionalne premije osiguranja i iznos režijskog dodatka. Visina premije zavisi od vrste rizika, vrednosti osigurane sume, dužine trajanja osiguranja i kamatne stope kojom se plasiraju sredstva osiguravajućeg fonda. [4]

Podaci o ukupnoj premiji osiguranja društava za osiguranje sačinjeni su na osnovu podataka NBS iz izveštaja za poslednji kvartal svake od posmatranih godina u okviru izveštaja koji su dostupni na njihovom sajtu.

U 2014. godini je 21 društvo za osiguranje ostvarilo ukupnu premiju u visini 69 milijardi dinara, dok je u 2016. godini 19 društava za osiguranje ostvarilo premiju od 89 milijardi dinara, što predstavlja nominalno povećanje za oko $30 \%$. U strukturi ukupne premije osiguranja, učešće životnih osiguranja povećalo se sa 23,1\% u 2014. godini na $23,9 \%$ u 2016. godini, dok se učešće premije neživotnih osiguranja smanjilo sa $76,9 \%$ na $74,1 \%$. 
Tabela 3. Ukupna premija osiguranja po osiguravajućim društvima, u hiljadama dinara, 2014.-2016. godine (kalkulacija na bazi javno dostupnih podataka NBS)

\begin{tabular}{|r|l|r|r|r|}
\hline \multicolumn{5}{|c}{ Ukupne premije po društvima za osiguranje- $\boldsymbol{u}$ 000 dinara } \\
\hline & & $\mathbf{2 0 1 4 . \text { god. }}$ & \multicolumn{1}{|c|}{ 2015. god. } & \multicolumn{1}{c|}{ 2016. god. } \\
\hline 1. & AMS osiguranje & 2.184 .085 & 2.482 .351 & 2.828 .404$. \\
\hline 2. & AS osiguranje & 228.129 & 128.274 & 0 \\
\hline 3. & AXA neživotno & 754.327 & 1.294 .442 & $1.921,033$ \\
\hline 4. & AXA životno & 115.065 & 181.027 & 226.425 \\
\hline 5. & DDOR Novi Sad & 9.507 .334 & 9.408 .425 & 10.329 .753 \\
\hline 6. & Generali osiguranje & 15.026 .269 & 18.632 .562 & 19.830 .102 \\
\hline 7. & Dunav osiguranje & 17.551 .843 & 21.461 .336 & 22.892 .695 \\
\hline 8. & Energoprojekt garant & 160.110 & 169.993 & 188.079 \\
\hline 9. & Globos osiguranje & 284.083 & 233.340 & 229.054 \\
\hline 10. & GRAWE osiguranje & 2.939 .543 & 3.285 .908 & 3.623 .593 \\
\hline 11. & Metlife & 112.730 & & 0 \\
\hline 12. & Merkur osiguranje & 791.108 & 957.229 & 1.110 .134 \\
\hline 13. & Milenijum osiguranje & 1.986 .130 & 2.550 .953 & 2.783 .525 \\
\hline 14. & Sava neživotno & 1.455 .219 & 1.741 .400 & 1.810 .318 \\
\hline 15. & Sava životno & 124.671 & 140.305 & 161.162 \\
\hline 16. & Societe general & 350.386 & 465.114 & 1.505 .863 \\
\hline 17. & Sogaz & 659.107 & 508.661 & 555.905 \\
\hline 18. & Triglav & 2.669 .972 & 3.404 .566 & 4.228 .896 \\
\hline 19. & Uniqa neživotno & 3.975 .572 & 4.190 .150 & 3.571 .652 \\
\hline 20. & Uniqa životno & 1.492 .018 & 1.817 .569 & 1.831 .023 \\
\hline 21. & Wiener & 7.037 .304 & 7.872 .183 & 9.510 .373 \\
\hline & UKUPNO & 69.405 .005 & 80.925 .788 & 89.137 .989 \\
\hline
\end{tabular}

\section{3. Životno i neživotno osiguranje}

Vrste životnih osiguranja su: osiguranje života, osiguranje za slučaj venčanja i rođenja, rentno osiguranje, dopunsko životno osiguranje, životna osiguranja vezana za jedinice investicionih fondova, tontine i osiguranje sa kapitalizacijom isplate. S tim u vezi, postoje društva koja imaju dozvolu za rad Narodne banke Srbije isključivo za obavljanje poslova životnih vrsta osiguranja ali i osiguravajuća društva koja obavljaju poslove životnih i neživotnih osiguranja. Bitno je istaći da društvo za osiguranje može obavljati poslove samo onih vrsta osiguranja za koje je dobilo dozvolu Narodne banke Srbije [1].

Ako posmatramo tržište životnog osiguranja, koje čini oko 1/4 ukupnog tržišta osiguranja, mogu se izdvajiti tri učesnika sa značajnim udelima: i to Generali osiguranje sa $34 \%$, zatim Wiener sa $20 \%$ i Grawe osiguranje sa $17 \%$ tržišta životnih osiguranja, koji zajedno čine oko $70 \%$ ukupnog tržišta životnog osiguranja.

Kao što smo istakli, društva za osiguranje mogu obavljati poslove osiguranja samo za one vrste osiguranja za koje imaju dozvolu Narodne banke Srbije.

Poslove neživotnih vrsta osiguranja obavljaju osiguravajuća društva koja imaju dozvolu za obavljanje sledećih vrsta neživotnog osiguranja: osiguranje od posledica nezgode, osiguranje motornih vozila, osiguranje šinskih vozila, osiguranje vazduhoplova, osiguranje plovnih objekata, osiguranje robe u prevozu, osiguranje imovine od požara, ostala osiguranja imovine, osiguranje od odgovornosti zbog upotrebe motornih vozila, osiguranje od odgovornosti zbog upotrebe vazduhoplova, osiguranje od odgovornosti zbog upotrebe plovnih objekata, osiguranje od opšte odgovornosti, osiguranje kredita, osiguranje jemstva, osiguranje finansijskih gubitaka, osiguranje troškova pravne zaštite i osiguranje pomoći na putovanju.Ukoliko posmatramo tržište neživotnog osiguranja, koje čini oko $3 / 4$ ukupnog tržišta osiguranja, prema visini premije izdvajaju se tri učesnika i to: Dunav osiguranje (33\%), Generali osiguranje (20\%) i DDOR Novi Sad (14\%) i oni čine blizu 70\% celokupnog tržišta neživotnog osiguranja.

Tržišno učešće osiguravajućih društava, prema kriterijumu ukupno ostvarene premije po godinama, predstavljena je u tabeli broj 4 :

Tabela 4. Tržišno učešće prema ukupnoj premiji (Kalkulacije na osnovu javno dostupnih podataka NBS)

\begin{tabular}{|c|l|c|c|c|}
\hline \multicolumn{5}{|c|}{ Tržišno učešće prema ukupnoj premiji } \\
\hline & & $\mathbf{2 0 1 4}$ & $\mathbf{2 0 1 5}$ & $\mathbf{2 0 1 6}$ \\
\hline \hline 1 & AMS osiguranje & $3,15 \%$ & $3,07 \%$ & $3,21 \%$ \\
\hline 2 & AS osiguranje & $0,33 \%$ & $0,16 \%$ & 0 \\
\hline 3 & AXA neživotno & $1,09 \%$ & $1,60 \%$ & $2,11 \%$ \\
\hline 4 & AXA životno & $0,17 \%$ & $0,22 \%$ & $0,32 \%$ \\
\hline 5 & DDOR Novi Sad & $13,70 \%$ & $11,63 \%$ & $11,86 \%$ \\
\hline 6 & Generali osiguranje & $21,65 \%$ & $23,02 \%$ & $23,30 \%$ \\
\hline 7 & Dunav osiguranje & $25,29 \%$ & $26,52 \%$ & $25,89 \%$ \\
\hline 8 & Energoprojekt garant & $0,23 \%$ & $0,21 \%$ & $0,32 \%$ \\
\hline 9 & Globos osiguranje & $0,41 \%$ & $0,29 \%$ & $0,28 \%$ \\
\hline 10 & GRAWE osiguranje & $4,24 \%$ & $4,06 \%$ & $4,26 \%$ \\
\hline 11 & Metlife & $0,16 \%$ & $/$ & $/$ \\
\hline 12 & Merkur osiguranje & $1,14 \%$ & $1,18 \%$ & $1,26 \%$ \\
\hline 13 & Milenijum osiguranje & $2,86 \%$ & $3,15 \%$ & $3,23 \%$ \\
\hline 14 & Sava neživotno & $2,10 \%$ & $2,15 \%$ & $2,18 \%$ \\
\hline 15 & Sava životno & $0,18 \%$ & $0,17 \%$ & $0,20 \%$ \\
\hline 16 & Societe general & $0,50 \%$ & $0,57 \%$ & $1,52 \%$ \\
\hline 17 & Sogaz & $0,95 \%$ & $0,63 \%$ & $0,80 \%$ \\
\hline 18 & Triglav & $3,85 \%$ & $4,21 \%$ & $4,52 \%$ \\
\hline 19 & Uniqa neživotno & $5,73 \%$ & $5,18 \%$ & $5,31 \%$ \\
\hline 20 & Uniqa životno & $2,15 \%$ & $2,25 \%$ & $2,01 \%$ \\
\hline 21 & Wiener & $9,21 \%$ & $10,14 \%$ & $7,42 \%$ \\
\hline & UKUPNO & $\mathbf{1 0 0 \%}$ & $\mathbf{1 0 0 \%}$ & $\mathbf{1 0 0 \%}$ \\
\hline
\end{tabular}

\subsection{Analiza tržišta osiguranja za 2017 i 2018 godinu}

Na kraju trećeg kvartala 2017. godine, u Srbiji je poslovalo 21 društvo za osiguranje, što čini dva društva manje nego $\mathrm{u}$ istom periodu prethodne godine. Poslovima reosiguranja bavilo se četiri društva dok isključivo poslovima osiguranja 17 društava. Od društava koja se bave poslovima osiguranja, isključivo životnim osiguranjem bavi se četiri društva, isključivo neživotnim osiguranjem sedam društava, a i životnim i neživotnim osiguranjem šest društava. Posmatrano prema vlasničkoj strukturi kapitala većinski udeo je u stranom vlasiništvu, gde je u premiji životnih osiguranja sa $93,0 \%$, premiji neživotnih osiguranja sa $61,5 \%$, ukupnoj imovini sa $77,0 \%$, kao i u broju zaposlenih sa $68,3 \%$.

Prema podacima objavljenim od strane Narodne banke Srbije, u prvoj polovini 2018. godine ostvaren je rast premije osiguranja kako u neživotnim, tako i u životnim osiguranjima. Time je nastavljen trend nominalnog rasta premije tržišta osiguranja koji traje već više od jedne decenije. 
Ukupna premija osiguranja tržišta u prvoj polovini 2018. godini prelazi $52 \mathrm{mlrd}$ RSD (442 mil. €), čime je zabeležen rast od $6,8 \% \mathrm{u}$ odnosu na isti period $\mathrm{u}$ prethodnoj godini. Istovremeno, zabeležena niska stopa inflacije čini da je i realna stopa rasta tržišta takođe relativno visoka, sa zabeleženih $11 \%$.

Ostvareni rast dobija na značaju kada se ima u vidu njegov opšti karakter, odnosno činjenica da je rast premije, bez izuzetka, zabeležen po svim vrstama osiguranja. Najveći nominalni rast zabeležen je u osiguranju od autoodgovornosti, već tradicionalno, kod osiguranja života, kao vrsti osiguranja sa najvećim potencijalom rasta. Opisana kretanja dovela su do toga da je povećano učešće životnih osiguranja u ukupnoj premiji, čime se domaće tržište kreće u pravcu strukture portfelja prisutnoj u državama sa razvijenim tržištima osiguranja. Ipak, nizak nivo životnog standarda i slabo razvijena svest o benefitima koje osiguranje nudi, uzrok su i dalje visokog učešća neživotnih osiguranja u ukupnoj premiji i to pre svega obaveznih osiguranja.

\section{ZAKLJUČAK}

Može se zaključiti da je tržište osiguranja u Srbiji u razvoju i da ima ogromne potencijalne mogućnosti, pre svega za razvoj životnog osiguranja. Dalje reforme sektora osiguranja u Srbiji treba da omoguće stvaranje finansijski pouzdanog i stabilnog tržišta osiguranja, na kojem će interesi osiguranika i korisnika osiguranja biti zaštićeni, a kvalitet u obavljanju delatnosti osiguranja podignut na viši nivo i usklađen sa standardima Evropske unije. Posebno treba obratiti pažnju na pojedine delove Zakona o osiguranju, koji ograničavaju investicionu aktivnost osiguravajućih kompanija.

\section{LITERATURA}

[1] Avdalović, V., (2007) Principi osiguranja. Fakultet tehničkih nauka. Novi Sad.

[2] Avdalović, V., (2007) Osiguranje. Beogradska bankarska akademija. Beograd.

[3] Avdalović, S., Ćosić, Đ., Avdalović, V., (2010) Osnove osiguranja sa upravljanjem rizikom. Fakultet tehničkih nauka. Novi Sad.

[4] Avdalović, V., Ćosić, Đ., Avdalović, S., (2008) Upravljanje rizikom u osiguranju. Fakultet tehničkih nauka. Novi Sad.

\section{Kratka biografija:}

Milan Bradić rođen je u Novom Sadu 1986. god. Master rad na Fakultetu tehničkih nauka iz oblasti Upravljanja rizikom i menadžmentom osiguranja odbranio je 2018.god. 